\title{
Anatomical and Biochemical Studies of Solanum melongena and Solanum nigrum
}

\author{
Okeke Philomena N*, Ilodibia Chinyere V, Ngene Anita C, Iroka Finian C Aziagba Bibian O \\ Department of Botany, Nnamdi Azikiwe University, Nigeria
}

Received October 20, 2019; Revised November 26, 2019; Accepted December 4, 2019

Copyright $\mathrm{C} 2020$ by authors, all rights reserved. Authors agree that this article remains permanently open access under the terms of the Creative Commons Attribution License 4.0 International License

\begin{abstract}
Anatomical, mineral and nutritional studies were carried out on various parts of Solanum nigrum and Solanum melongena using standard techniques. Analysis of variance was employed for data analysis. Anatomical studies showed that the two species have similar features in the transverse sections of their leaves and stem but have dissimilar features in the transverse sections of their roots. The mineral result revealed varying quantities of the minerals in the various parts of the two species. The highest mineral composition in $S$. melongena was selenium $(1030.0 \pm 10.0)$ which was found in the root, while potassium $(2.75 \pm 1.59)$ which was found in the stem was the least. The highest mineral composition in S. nigrum was calcium $(873.33 \pm 16.67)$ which was found in the leaves, while potassium was the least $(2.26 \pm 0.55)$ found in the root. Vitamin studied showed varying quantities of the vitamins in the various parts of the two species. The highest vitamin was vitamin $\mathrm{A}$ in the root of both species when compared to the other parts. The implication is that the two species are closely related and this justified their placement in the same genus Solanum while the slight difference between them supports their separation into different species. The result also indicated that the various part of the two species contained adequate amount of vitamins and minerals for human consumption.
\end{abstract}

Keywords Anatomical, Mineral, Vitamins, Solanum melongena, Solanum nigrum

\section{Introduction}

The Solanaceae family comprises about 98 genera and 2,700 species with a wide distribution, mainly in the tropical and subtropical regions of the world (Olmstead and Bohs, 2007). Solanum melogena L. and Solanum nigrum L. belong to the family Solanaceae (Order-Solanales). They are dicotyledonous plants bearing barriers with numerous seeds. According to Hunziker (1979) Solanum species are herbs, leaves are simple, pinnate and alternate. Flowers are radically or rarely bilaterally symmetrical, with hypogenous discs; sepals are usually coalescent for almost their full length, the calyx is persistent often enlarging in fruits, corolla ovate to tabular, carpel 2 , the style 1 , and the ovary usually 2 chambered or sometimes 3-5 through irregularities of the placenta, parental-axile, ovules numerous in each carpel, fruit berry.

Economically, members of Solanum used are for the production of drugs e.g. pharmaceutical steroids. The leaf juice is used in treating inflammation of the kidney and bladder and in gonorrhea, dropsy, heart diseases, bile and enlargement of the spleen (Pandey et al., 2000). Solanum species have indigenous medicinal uses which range from weight reduction to treatment of several ailments including asthma, skin infections and constipation. Various plant parts are used in decoction for curing ailments such as diabetes, leprosy, haemorrhoids (Bello et al., 2013). More so, the plants are known for their rich nutritional and mineral value. Physiognomic characters, phytochemicals and anatomical properties of plant parts are sources for taxonomic inferences in different groups of flowering plants (Harborne, 1973; Buchanan et al., 2000).Therefore, the objectives of this study is to provide empirical data on the morphology, anatomy and nutrition of these varieties of Solanum species for accurate description and proper identification. This would go a long way in creating awareness and improve the consumption rate of these plants Ahmad et al., (2010).

\section{Materials and Methods}

Sources of materials: Samples of S. melongena and $S$. nigrum were collected from Agricultural Development Programme (ADP) farm in Awka North Local Government Area Anambra State and authenticated by a curator in the agency. 
Anatomical analysis: Anatomy follows the method of (kadiri and Adeniran, 2016) with some modification. The stem and midrib samples were freely sectioned using razor blade and the thin slices obtained were kept in water before transferring onto a glass slide where a few drops of $99 \%$ ethyl alcohol were added for tissue hardening and then 2 drop of safranin solutions. Excess stain was washed off with water before a drop of glycerin was added. Slides were covered with cover slips and ringed with nail lacquer. However, all preparations were observed with an Olympus microscope and photographs were taken with a digitized camera (Nikkon).

Mineral analysis: The species $S$. melongena and $S$. nigrum used for the study were harvested fresh. The leaves, stem and root were separated and washed with clean cold tap water and sum derived for 2 weeks. After drying, the leaves were grounded into a fine powder using a mortar and pestle, sieved and stored in air-light containers. The minerals in the leaf, stem and root analyzed from solution were obtained when $5 \mathrm{~g}$ of the samples were digested with $10 \mathrm{ml}$ of SN concentrated hydrochloride. The mixtures were placed on a water bather and evaporated almost to dryness. The solution were cooled and filtrated into standard flask and diluted to volume with distilled water. Each experiment was repeated three times.

Determination of calcium (Ca) and Magnesium (Mg): The versanate EDTA titrimetric method of Udoh and Oguwale (1986) was employed. 20mls portion of each extract was dispersed into conical flask and treated with inches of masking agents (hydroxylamine hydrochloride, sodium cyanide and sodium potassium ferrocyanide). The flask was shaken and the mixture dissolved. $20 \mathrm{mls}$ of ammonia was added to it to raise the $\mathrm{p}^{\mathrm{H}}$ to 10.00 (a point at which both calcium and magnesium form complexes with EDTA). The mixture was titrated against $0.02 \mathrm{~N}$ EDTA solution using Erochiome Black $\mathrm{T}$ as indicator. A reagent black was titrated and titration in each case was done from deep red to a permanent blue endpoint. The titration value represents both calcium and magnesium ions in test sample. A repeat titration was done $\mathrm{Ca}^{2+}$ alone in the test samples, $10 \% \mathrm{NaOH}$ was used in place of the ammonium buffer and solechrome dark blue indicator in place of Erichrome Black T

Determination of Potassium (K): The potassium content was determined by flame photometry. About $5 \mathrm{mls}$ of the sample was pipetted into a test tube in duplicate. Then $2 \mathrm{mls}$ of cobalt nitrite was added, shaken vigorously and allowed to stand for $45 \mathrm{mins}$ and centrifuged for $15 \mathrm{mins}$. The supernatant was drained-off and $2 \mathrm{mls}$ of ethanol was added to the residue. The solution was shaken vigorously and centrifuged off and $2 \mathrm{ml}$ of distilled water was boiled for 10 minutes with frequent shaking to dissolve the precipitate. About $1 \mathrm{ml}$ of $1 \%$ chorine hydrochloride and $1 \mathrm{ml}$ of $2 \%$ sodium ferric cyanide was added. Then $2 \mathrm{mls}$ of distilled water was also added and then the solution was shaken to mix well. The absorbance was taken at 620nm against the blank.

Determination of Heavy Metals (zinc, lead, iron, selenium and manganese): $3 \mathrm{~g}$ of each sample was weighed with electronic weighing balance into a $250 \mathrm{ml}$ beaker. $10 \mathrm{ml}$ of $\mathrm{HCl}$ was measured using measuring cylinder into the beaker containing the samples and kept for 2-3 minutes. Then $30 \mathrm{ml}$ of Nitric acid was measured also and added into the beaker of the sample. The beaker was heated on a hot plate for about 10-15 minutes at a temperature of between $65^{\circ} \mathrm{C}$ and $70^{\circ} \mathrm{C}$ to digest in the fume cupboard and the beaker removed from the hot plate and kept to cool (Ademoroti, 1996). After cooling, the digested sample was filtered into another beaker using funnel with filter paper, distilled water added into the filtrate to make up to $100 \mathrm{ml}$ and ready for analysis. The digested solutions were analyzed for the presence of zinc, lead, iron, selenium and manganese using atomic absorption spectrophotometer (Unicam 939 AAS) with different lamps in position.

\section{Vitamin Analysis}

\section{Preparation of Sample:}

The species $S$. melongena and $S$. nigrum used for the study was harvested fresh, the leaves, stem and root was separated and washed with clean cold tap water and sum derived for 2 weeks. After drying, the eaves were grounded into a fine powder using a mortar and pestle, sieved and stored in air-light containers.

The vitamins in the leave, stem and root of $S$. melongena and $S$. nigrum were determined by the official methods of the Association of official Analytical chemist (AOAC, 1990).

Determination of Vitamin A (Retinol): A quantity, one gram of the sample was weighed and macerated with $20 \mathrm{ml}$ of $\mathrm{n}$-hexane in a test tube $10 \mathrm{mins}$. The $3 \mathrm{~ms}$ of the upper hexane extract was transferred into a dry test tube in duplicates and evaporated to dryness. Following this, $0.2 \mathrm{ml}$ of acetic anhydride chloroform reagent was added and $2 \mathrm{ml}$ of $50 \%$ trichloroacetic acid (TCA) in chloroform was also added. The absorbance was taken at 15 seconds and 30 seconds interval at $620 \mathrm{mn}$.

Determination of Vitamin C: About $0.5 \mathrm{~g}$ of the sample was weighted macerated with $10 \mathrm{mls}$ of $0.4 \%$ oxalic acid in a test tube for $10 \mathrm{mins}$, centrifuged for $5 \mathrm{mins}$ and the solution filtered. $1 \mathrm{ml}$ of the filtrate was duplicated, $9 \mathrm{mls}$ of 2, 6- dichlorephenol-indophenols was added and absorbance was taken at $15 \mathrm{sec}$ and $30 \mathrm{sec}$ interval at $520 \mathrm{~nm}$. 
Determination of Vitamin E (Tocophenol): $1 \mathrm{~g}$ of the original sample was weighed, macerated with $20 \mathrm{ml}$ of $\mathrm{n}$-hexane in a test tube for 10 minutes and centrifuged for $10 \mathrm{mins}$. The solution was filtered; $5 \mathrm{mls}$ of the filtrate was transferred into a dry test tube in duplicates and evaporated to dryness in a boiling water bath. Following this, $2 \mathrm{mls}$ of $0.5 \mathrm{n}$ alcoholic potassium hydroxide was added and boiled for 30 minutes in a water bath. Then $3 \mathrm{mls}$ of $\mathrm{n}$-hexane was added and was shaken vigorously. The $\mathrm{n}$-hexane was transferred into another set of test tubes and evaporated to dryness. A volume, $2 \mathrm{mls}$, of ethanol was added to the residue.

Another volume, $1 \mathrm{ml}$ of $0.2 \%$ ferric chloride in ethanol was added. The $1 \mathrm{ml}$ of $0.5 \% \alpha^{\text {ii }} \alpha^{\mathrm{i}}$-dipyridyl in ethanol was added followed by the addition of $1 \mathrm{ml}$ of ethanol to make it up $5 \mathrm{mls}$. The solution was mixed and absorbance taken at $500 \mathrm{~nm}$ against the blank.

\section{Results}

\subsection{Mineral Analysis Result}

Table 1. Mineral composition of S. nigrum and S. melongena

\begin{tabular}{|c|c|c|c|c|c|c|}
\hline $\begin{array}{c}\text { Mineral } \\
(100 \mathrm{ml})\end{array}$ & $\begin{array}{c}\text { Leave of S. } \\
\text { nigrum }\end{array}$ & $\begin{array}{c}\text { Leave of S. } \\
\text { melongena }\end{array}$ & $\begin{array}{c}\text { Stem of S. } \\
\text { nigrum }\end{array}$ & $\begin{array}{c}\text { Stem of S. } \\
\text { melongena }\end{array}$ & $\begin{array}{c}\text { Root of S. } \\
\text { nigrum }\end{array}$ & $\begin{array}{c}\text { Root of S. } \\
\text { melongena }\end{array}$ \\
\hline Calcium & $873.33 \pm 16.67$ & $738.16 \pm 11.17$ & $553.66 \pm 18.70$ & $775.40 \pm 8.16$ & $387.33 \pm 35.00$ & $721.23 \pm 10.12$ \\
\hline Potassium & $4.10 \pm 1.53$ & $2.75 \pm 1.59$ & $3.50 \pm 1.10$ & $1.15 \pm 1.66$ & $2.26 \pm 0.55$ & $4.90 \pm 1.71$ \\
\hline Magnesium & $44.45 \pm 0.89$ & $39.35 \pm 065$ & $40.40 \pm 0.75$ & $33.09 \pm 1.80$ & $29.46 \pm 0.40$ & $32.38 \pm 2.10$ \\
\hline Selenium & $730.0 \pm 30.0$ & $745.01 \pm 13.5$ & $680.0 \pm 14.05$ & $810.11 \pm 14.16$ & $655.0 \pm 55.00$ & $1030.0 \pm 10.01$ \\
\hline Zinc & $248.33 \pm 8.33$ & $491.66 \pm 85.00$ & $150.10 \pm 16.40$ & $259.41 \pm 15.40$ & $123.33 \pm 3.33$ & $146.66 \pm 3.33$ \\
\hline Iron & $64.81 \pm 0.96$ & $65.84 \pm 0.78$ & $51.01 \pm 2.05$ & $62.41 \pm 2.11$ & $36.86 \pm 2.17$ & $59.03 \pm 4.10$ \\
\hline Lead & $49.35 \pm 60.73$ & $65.47 \pm 43.58$ & $57.61 \pm 14.76$ & $57.79 \pm 18.10$ & $68.68 \pm 85.42$ & $62.52 \pm 8.42$ \\
\hline Manganese & $72.56 \pm 2.31$ & $75.63 \pm 5.89$ & $88.72 \pm 1.40$ & $90.01 \pm 5.14$ & $102.04 \pm 0.51$ & $120.5 \pm 9.74$ \\
\hline
\end{tabular}

\subsection{Results are in Mean \pm Standard Deviation}

The result showed varying quantities of the mineral in the various parts of S. melongena and S. nigrum (Table 1). The highest mineral composition in S. nigrum was calcium $(873.33 \pm 16.67)$ found in the leaves while potassium was the least composition (2.26 \pm 0.55) found in the roots. The highest mineral composition in $S$. melongena was selenum $(1030.0 \pm 10.01)$ found in the root while potassium $(2.75 \pm 1.59)$ found in the leave was the lowest mineral composition.

Table 2. Vitamin composition of S. nigrum and S. melongena

\begin{tabular}{|c|c|c|c|c|c|c|}
\hline $\begin{array}{c}\text { Nutrient } \\
(100 \mathrm{ml})\end{array}$ & $\begin{array}{c}\text { Leave of S. } \\
\text { nigrum }\end{array}$ & $\begin{array}{c}\text { Leave of S. } \\
\text { melongena }\end{array}$ & $\begin{array}{c}\text { Stem of S. } \\
\text { nigrum }\end{array}$ & $\begin{array}{c}\text { Stem of S. } \\
\text { melongena }\end{array}$ & $\begin{array}{c}\text { Root of S. } \\
\text { nigrum }\end{array}$ & $\begin{array}{c}\text { Root of S. } \\
\text { melongena }\end{array}$ \\
\hline Vitamin C & $3.18 \pm 0.76$ & $0.92 \pm 0.03$ & $1.08 \pm 0.10$ & $1.12 \pm 0.12$ & $1.21 \pm 0.05$ & $1.62 \pm 0.63$ \\
\hline Vitamin A & $54.99 \pm 2.23$ & $64.82 \pm 2.02$ & $66.52 \pm 2.80$ & $70.28 \pm 3.30$ & $94.66 \pm 3.22$ & $92.45 \pm 4.21$ \\
\hline Vitamin E & $4.70 \pm 0.36$ & $5.10 \pm 0.74$ & $5.15 \pm 0.74$ & $5.55 \pm 0.80$ & $7.34 \pm 1.49$ & $6.10 \pm 1.24$ \\
\hline
\end{tabular}

\subsection{Results Are in Mean \pm Standard Deviation}

The result showed varying quantities of the vitamin in the various parts of S. nigrum and S. melongena (Table 2). The highest vitamin composition for S. nigrum vitamin A $(94.66 \pm 3.22)$ found in the roots while the least was Vitamin C $(1.08 \pm 0.10)$ found in the stem. Also, the highest vitamin composition for S. melongena was vitamin A $(92.45 \pm 4.21)$ found in the roots while the least was $(0.92 \pm 0.03)$ found in the leaves. 
3.4. Transverse Section of the Leaf, Stem and Root of $S$. nigrum and $S$. melongena
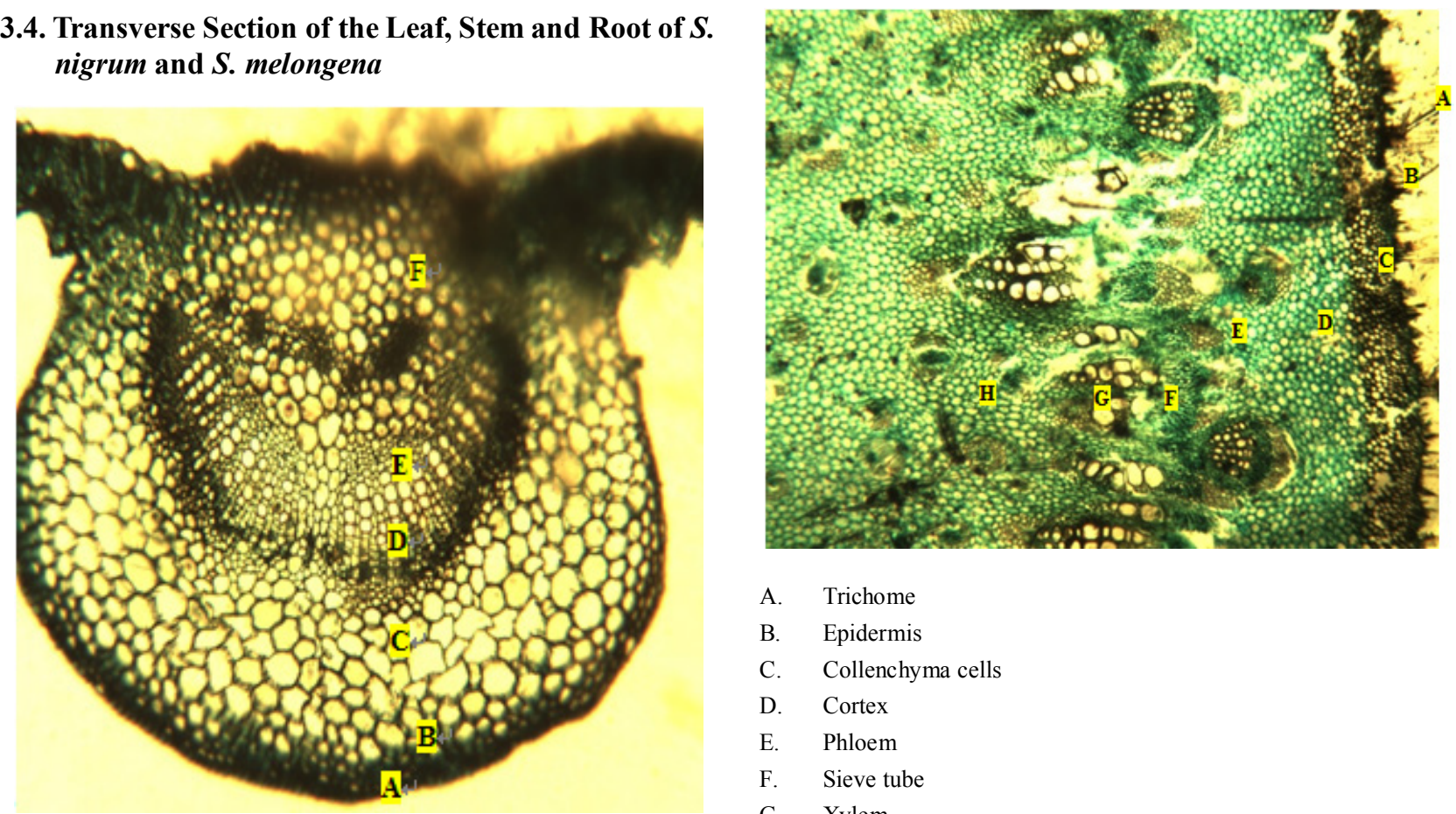
A. Trichome
B. Epidermis
C. Collenchyma cells
D. Cortex
E. Phloem
F. Sieve tube
G. Xylem
H. Pith
B. Collenchyma cells
C. Cortex
D. Phloem
E. Xylem
F. Pith

Plate 1. T/S of leaf of Solanum melongena $\times 100$

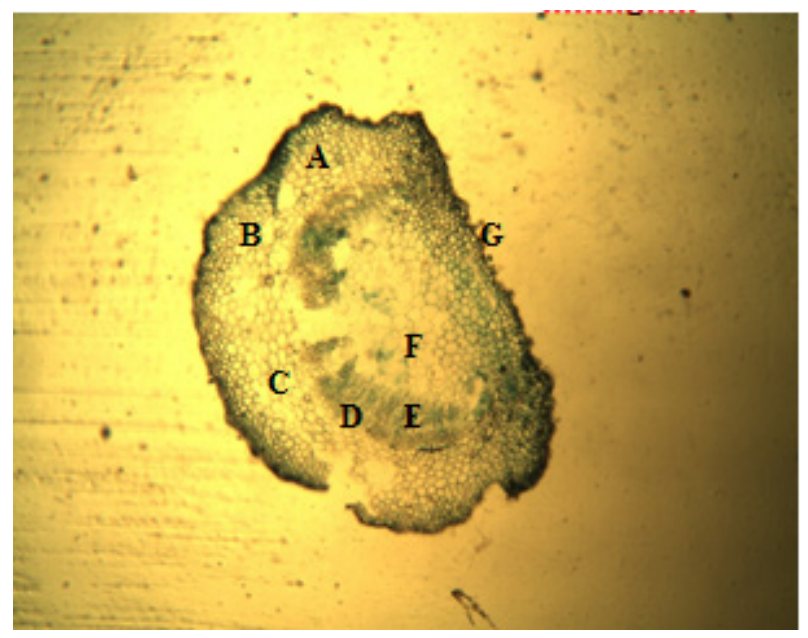
A. Epidermis
B. Parenchyma cells
C. Cortex
D. Phloem
E. Xylem
F. Pith
G. Trichome

Plate 3. $\mathrm{T} / \mathrm{S}$ of stem of Solanum melongena $\times 100$

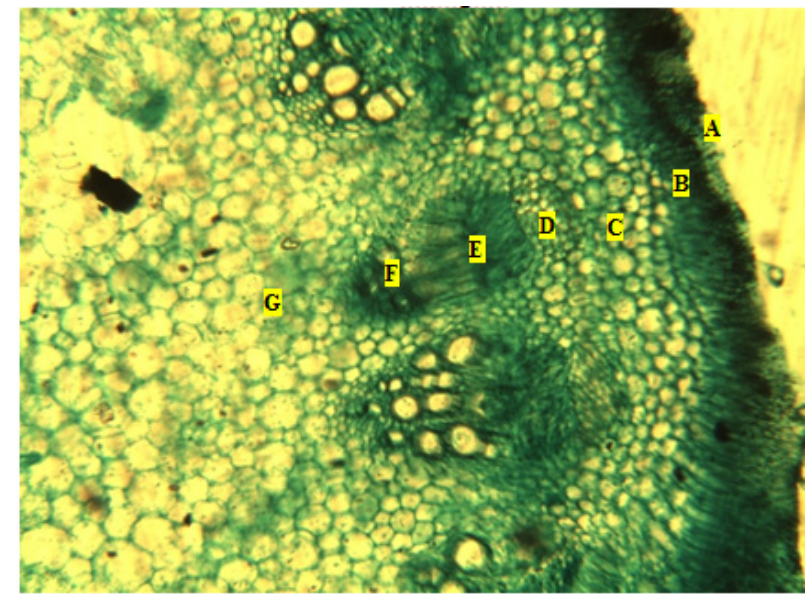
A. Epidermis
B. Collenchyma cells
C. Cortex
D. Parenchyma cells
E. Phloem
F. Xylem
G. Pith

Plate 4. $\quad \mathrm{T} / \mathrm{S}$ of stem of Solanum nigrum $\times 100$

Plate 2. T/S of leaf of Solanum nigrum $\times 40$ 


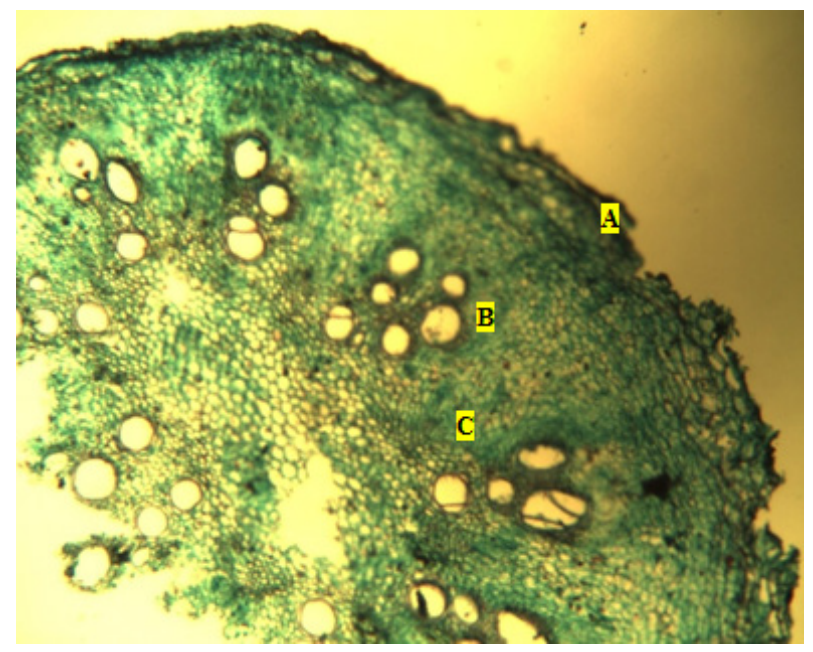
A. Cork
B. Cortex
C. Stele

Plate 5. $\mathrm{T} / \mathrm{S}$ of root of Solanum melongena $\times 100$

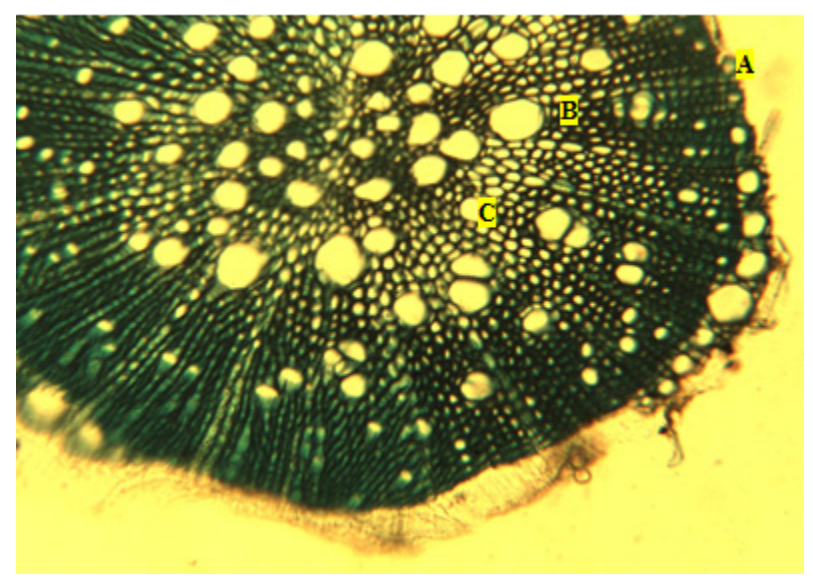
A. Cork
B. Cortex
C. Stele

Plate 6. $\mathrm{T} / \mathrm{S}$ of root of Solanum nigrum $\times 40$

\section{Discussion and Conclusions}

In the anatomy of $S$. melongena, the mid-rib showed stellate trichomes in the epidermis made of a layer of cells. The collenchymatous cells occupy the region of the hypodermis; parenchymatous cells occupy the ground meristem. The primary growth phase reveals 3 vascular traces with no rib bundle wings in both growth phases (plates 1 and 2). On the other hand, the mid-rib of S. nigrum was similar to that of $S$. melongena. The mid rib of $S$. melongena is made of a layer of cells in the epidermis the cell and tissue arrangements and is similar in mid-rib of both plants except that there are 2 to 4 rib bundle wings present in the mid rib of $S$. melongena. Stem anatomy has an epicycle of many layers of cells below the endodermis (inner-most part of the cortex) and large pith occupied by collenchymatous cells (plates 3 and 4). Also, the root anatomy of $S$. melongena revealed epiblema made of one layer. The vascular bundles have radial symmetry (plates 5 and 6).

Relatively, the mid-rib of $S$. nigrum showed numerous simple multicellular trichomes on the epidermal layer made of a roll cells. The hypodermis is made of few layers of thick wall cells termed collenchymas, the vest of the general cortex is composed of parenchymatous cells which are larger and made of this wall. Moreover, the mid rib of $S$. melongena has the same pattern of cell arrangement as in $S$. melongena expect that there are less tanniferous cells than the former.

On the other hand, table 1 showed mineral contents respectively. Selanium content showed significant values from $655 \pm 55.0 \mathrm{~b}$ to $1030.0 \pm 10.01 \mathrm{Mg} / 100 \mathrm{ml}$. Calcium content ranged from $387.33 \pm 53.00$ to $873.33 \pm 16.67$ $\mathrm{mg} / 100 \mathrm{ml}$ in both S.melongena and S.nigrum respectively. These values are higher than the values reported for some selected vegetable leaves in Nigeria, such as Amaranthus hybridus, Hibiscus sabdariffa and Telfaria occidentallis (Asaolu et al., 2012) Potassium content ranged from 2.26 0.55 to $4.90 \pm 1.71 \mathrm{mg} / 100 \mathrm{ml}$ for the two species. The values were lower when compared with standard dietary allowance (RDA). The magnesium content ranged from $29.40 \pm 0.40$ to $44.45 \pm 0.89 \mathrm{mg} / 100 \mathrm{ml}$. the values obtained in these studies are low to meet the recommended daily allowance (RDA) of $400 \mathrm{mg} /$ day for men, women of 19 to 39 years old (Food and Nutrition Board, 1997).

More so, the iron content varies from $36.86 \pm 2.17$ to $65.84 \pm 0.7 \mathrm{mg} / 100 \mathrm{ml}$ in both plants. The values were significantly higher than the values reported for some other vegetables in Nigeria (Chinma and Igyor, 2007). Iron is however, a part of the haemoglobin $(\mathrm{Hb})$, myoglobin, and Cytochromes (Chandra, 1990). The content of Zinc ranged from $123.33 \pm 3.33$ to $491.66 \pm 85.00 \mathrm{mg} / \mathrm{ml}$ in both plants respectively and these were significantly higher when compared with the standard recommended dietary allowance (RDA)

The result of the vitamin composition of the two Solanum species studied is present in table 2. Vitamin A content ranged from $54.99 \pm 2.23$ to $94.66 \pm 3.22 \mathrm{mg} / 100 \mathrm{ml}$ as found in both plants. Hence, vitamin A is important for normal vision, gene expression, growth and immune function by its maintenance of epithelial cell functions (Lukaski, 2004). Solamum nigrum had (3.18 \pm $0.0 \mathrm{mg} / 100 \mathrm{ml}$ ) of vitamin $\mathrm{C}$ in its leaves as compared to $0.92 \pm 0.03 \mathrm{mg} / 100 \mathrm{ml}$ found in the leaves of Solamum melongena. Vitamin $\mathrm{C}$ helps in the reduction of folic acid intermediates and the synthesis of cortisol. Its deficiency includes fragility to blood capillaries, gum decay, scurvy. Lastly, Vitamin E content varied from $7.34 \pm 1.49 \mathrm{mg} / 100 \mathrm{ml}$ to $4.14 \pm 0.89 \mathrm{mg} / 100 \mathrm{ml}$ in both plants. Vitamin $\mathrm{E}$ is a powerful antioxidant which helps to protect cells from damage by free radicals and to the formation and normal 
function of red blood cell and muscles (Lukaski, 2004).

This study which spans through the anatomical, and mineral and vitamin analyses of $S$. melongena and $S$. nigrum revealed various features. Thus, the implication is that the two species are closely related and this justified their placement in the same genus Solanum while the slight difference between them supports their separation into different species. The result also indicated that the various parts of the two species contained adequate amount of vitamins and minerals for human consumption.

\section{REFERENCES}

[1] Ademoroti, C. M. A. Standard Methods for Water and Effluents Analysis, Foludex Press Ltd, Ibadan, Nigeria. Pp. 36-80, 1996

[2] Ahmad, M., Kashmiri, M. A. and Mihy-ud-dint, A. Chemotaxonomic value of alkaloids in Solanum nigrum complex. Pakistan journal of Botany. 42 (1): 653-660, 2010

[3] Asaolu, M. F. Proximate and mineral composition of cooked and uncooked Solanum melongena. Int. J. of Food Sci. Nutr. 53:103-107, 2012.

[4] AOAC. Official methods of food analysis (15th edition) Williams S. (ed) Association of official Analytical Chemists, Washington D.C Pp 152-164, 1990.

[5] Bello, A. O., Oladipo, O. T. and Saheed, S. A. Numerical taxonomic study of some Solanum L. species (Solanaceae) using vegetative and floral morphological characteristics. Ife Journal of Sci. 15(3):523-534, 2013.

[6] Buchanan, B. B., Gruissem, W. and Jones, R. L. Biochemistry and molecular biology of plants. Rockville, Maryland, USA: American Society of Plant Physiologists, 2000 .

[7] Chandra, R.K. (1990). Micronutrients and Immune functions and overview. Ann. New York Acad. Sci. 587: 9-16.

[8] Chinma, C.E.M. and Igyor, M.A. Micronutrients and anti-nutritional contents of selected tropical vegetables grown in southeastern Nigeria. Nig. Food. Jour. 25(1): 111-116, 2007.

[9] Food and Nutrition Board. Dietary reference intakes for calcium, phosphorus, magnesium, vitamin D, and fluoride. Washington (DC): National Press (US), 1997.

[10] Harborne, J. B. Phytochemical methods: A guide to modern techniques of plant analysis. Chapman and Hall Ltd; London. Pp 279, 1973

[11] Hunziker, A. T. South American Solanaceae: a synoptic review. in: DARCY, W. G., 1979: The Biology and Taxonomy of the Solanaceae. Linn. Soc. Symp. Ser. 7: Pp 48-85, 1979.

[12] Kadiri, A. B. and Adeniran, S. Study of anatomy of the genus Hura L. (Euphorbiaceae). Ife Journal of Science 18(2): 413-426, 2016.

[13] Lukaski, C.H. Vitamin and Mineral stayus. Effects on physical performance. Nutritional research center. Grand forks, Northern Dakota, USA, 20: 632-644, 2004.

[14] Olmstead, R. G. and Bohs, L. A. A Summary of molecular systematic research in Solanaceae: Acta Horticulture. 745(745): 255-268, 2007

[15] Pandey, A., Soccol, C. R., Nigam, P., Soccol, V. T., Vandenberghe, L. P. S and Mohan, R. Biotechnological potential of agro-industrial residues II: cassava bagasse. Bioresource Technol., 74(1): 81-87, 2000.

[16] Udoh, B. I. and Oguwale, N. C. Mineral quantitative analysis. J. African food chem. 4(11): 5489-5493, 1986. 